ISSN: 2302-8556

E-Jurnal Akuntansi Universitas Udayana

Vol.23.3.Juni (2018): 1708-1735

DOI: https://doi.org/10.24843/EJA.2018.v23.i03.p04

\title{
Budaya Organisasi Sebagai Pemoderasi Pengaruh Kompetensi dan Locus Of Control Pada Kinerja Auditor Kantor Akuntan Publik di Provinsi Bali
}

\author{
I Dewa Ayu Yulia Rusmita ${ }^{1}$ \\ I Dewa Nyoman Badera ${ }^{2}$
}

${ }^{1}$ Fakultas Ekonomi dan Bisnis Universitas,Udayana (Unud), Bali, Indonesia
email :liayulia166@gmail.com/ Telp:+6282247874747
${ }^{2}$ Fakultas Ekonomi dan Bisnis Universitas Udayana (Unud), Bali, Indonesia

\begin{abstract}
ABSTRAK
Kinerja akutan publik yang berkerja didalamnya mencerminkan Kualitas Kantor Akuntan Publik (KAP). Kinerja auditors merupakan perwujudan kerja yang dilakukan untuk mencapai hasil kerja yang lebih baik untuk pencapaian tujuan organisasi. Faktor yang mempengaruhi kinerja auditor yaitu kompetensi, locus of control dan budaya organisasi. Tujuan dari penelitian ini adalah untuk mengetahui moderasi budaya organisasi dengan kompetensi dan locus of control pada kinerja auditor. Penelitian ini dilakukan pada Kantor Akuntan Publik di Provinsi Bali. Sampel yang di ambil dalam penelitian ini sebanyak 67 auditor. Dalam penelitian ini dilakukan pengumpulan data menggunakan metode survei dengan teknik kuisioner. Teknik analisis yang digunakan adalah Moderated Regression Analysis (MRA). Berdasarkan hasil analisis ditemukan bahwa kompetensi dan locus of control berpengaruh positif dan signifikan pada kinerja auditor. Budaya organisasi memperkuat pengaruh kompetensi dan locus of control pada kinerja auditor.
\end{abstract}

Kata Kunci: kompetensi, locus of control, budaya organisasi, kinerja auditor

\begin{abstract}
The performance of public accountants working within them reflects the Quality of Public Accounting Firm (KAP). Auditor performance is a manifestation of work done to achieve better work for the achievement of organizational goals. Factors affecting the auditor's performance are competence, locus of control and organizational culture. The purpose of this research is to know the moderation of organizational culture with competence and locus of control on auditor performance. This research was conducted at Public Accounting Firm in the Province of Bali. The samples taken in this study were 67 auditors. In this research conducted data collection using survey method with questionnaire technique. The analysis technique used is Moderated Regression Analysis (MRA). Based on the analysis result found that competence and locus of control have positive and significant influence on auditor performance. Organizational culture strengthens the influence of competence and locus of control on auditor performance.

Keywords: competence, locus of control, organizational culture, auditor performance
\end{abstract}

\section{PENDAHULUAN}

Kebutuhan perusahaan atas pengauditan kegiatan perusahaan menunjukkan sangat pentingnya auditor di dalam dunia perekonomian. Karena hal tersebut maka Kantor Akuntan Publik (KAP) harus selalu meningkatkan kualitas jasa audit yang dilakukan para auditor. Kualitas Kantor Akuntan Publik (KAP) dapat di lihat dari kinerja 
Akutan Publik yang bekerja didalamnya (Sitio dan Anisykurlillah, 2014). Kantor Akuntan Publik (KAP) merupakan organisasi yang memberikan jasa berupa jasa audit operasional, audit kepatuhan dan audit laporan keuangan (Arens dan Loebbecke, 2003:4) dalam Safitri (2014). Dalam mengerjakan tugas pemeriksaan, kantor akuntan publik membutuhkan dukungan dari kinerja Auditor. Kinerja auditor yang baik dapat meningkatkan kepercayaan dari masyarakat pada jasa yang disediakan oleh KAP.

Kinerja auditor merupakan perwujudan kerja yang dilakukan untuk mencapai hasil kerja yang lebih baik untuk pencapaian tujuan organisasi. Kinerja auditor juga menjadi tolak ukur kesuksesan suatu tugas untuk mengatasi masalah yang terjadi pada beberapa kasus keuangan dan menjadi perhatian utama. Seorang auditor di tuntut untuk memperoleh bukti yang objektif dan handal sehingga hasil pengauditan dapat dipertanggungjawabkan. Pengawasan yang kurang terhadap auditor, dapat membuat auditor melakukan manipulasi untuk kepentingan bersama atau kelompok maupun kepentingan individual.

Auditor merupakan akuntan publik yang memberikan jasa audit dan ditugaskan untuk mengumpulkan serta memeriksa bukti audit untuk memastikan kesesuaian informasi dengan kriteria yang ditetapkan dan kemudian mengkomunikasikan terhadap pengguna. Peluang mendeteksi kesalahan terkait pada kompetensi auditors. Kompetensi di ukur dari kemampuan auditor, seperti tingkat pengalaman, spesialisasii auditor, jamm audit, dan lain-lain (Fitriany, 2010). 
ISSN: 2302-8556

E-Jurnal Akuntansi Universitas Udayana

Vol.23.3.Juni (2018): 1708-1735

Kompetensi yang dimiliki setiap individu menentukan kemampuan auditor dalam melakukan tugas.

Penelitian yang dilakukan oleh Yusri Kasim (2013) menyebutkan bahwa Kompetensi secara parsial berpengaruh positif terhadap kinerja Auditor. Terdapat hubungan antara kompetensi dan kinerja auditor dimana auditor yang mempunyai keahlian cukup, pasti dapat menyelesaikan tugas pemeriksaan dengan baik sehingga nantinya kinerjanya semakin meningkat. Sedangkan berbeda dengan hasil penelitian tersebut, dalam penelitian Salju (2015) menunjukkan bahwa kompetensi secara parsial tidak berpengaruh terhadap kinerja auditor.

Falikhatun $(2003 ; 264)$ dalam Ayudiati (2010) menyatakan bahwa peningkatan kinerja pada pekerjaan dipengaruhi kondisi seperti kondisi yang bersumber dari dalam individu yang di sebut faktor individual sedangkan kondisi yang berasal dari luar individu di sebut faktor situasional. Terkait dengan faktor individual, locus of control merupakan indikator yang mempengaruhi prestasi kerja auditor. Menurut Setiawan dan Ghozali (2006:6), locus of control atau pusat kendali menunjukkan seberapa yakin individu bahwa ia dapat mengendalikan faktor yang mempengaruhi dirinya.

Penelitian yang dilakukan oleh Faridah (2017) menunjukkan bahwa locus of control berpengaruh positif terhadap kinerja. Dimana auditor yang dapat mengendalikan aktivitas dan perilakunya dalam penugasan audit maka akan dapat berpengaruh pada kinerjanya. Hai ini sejalan dengan penelitian yang dilakukan oleh 
Julianingtyas (2012), Putra dan Ariyanto (2016), Sanjiwani dan Wisadha (2016). Sedangkan berbeda dengan penelitian tersebut, dalam penelitian yang dilakukan oleh Ceacilia (2015) menunjukan bahwa locus of control berpengaruh negatif terhadap kinerja auditor.

Berdasarkan uraian penelitian pengaruh kompetensi dann locus of control pada kinerja auditor terdapat hasil yang tidak konsisten, dimana diduga terdapat faktor lain yang memengaruhi hubungan antara variabel independen dengan variabel dependennya. Maka dari itu untuk dapat merekonsiliasi hasil yang bertentangan atau tidak konsisten tersebut diperlukan variabel lain yang bertindak sebagai pemoderasi dalam model riset. Dari hasil riset empiris terdapat variabel yang diduga berperan dalam memoderasi pengaruh kompetensi dan locus of control pada kinerja auditor yaitu budaya organisasi.

Budaya merupakan salah satu faktor eksternal yang berpengaruh terhadap kinerja auditor. Budaya organisasi diyakinii adalah faktor yang menentukan kesuksesan kinerja ekonomi suatuu organisasi, karena budaya organisasi merupakan keyakinan dasar yang melandasi visi-misi, tujuan serta nilai yang di anut semua anggota organisasi dari karyawan pada level terendah sampai pemimpin. Budaya organisasi dan lingkungan kerja yang kondusif mempengaruhi hasil kerja yang dicapai oleh auditor.

Penelitian yang dilakukan oleh Syauffa (2016) menyebutkan bahwaa budaya organisasi berpengaruhh positif terhadap kinerja Auditor. Semakin baik budaya 
ISSN: 2302-8556

organisasi yang di terapkan oleh auditor maka kinerja auditor akan semakin baik. Semakin baik budaya organisasi di suatu perusahaan akan menjadikan auditor berpikir, berperilaku, dan bersikap sesuai dengan nilai organisasi yang mencangkup profesionalisme, kepercayaan, keteraturan serta integrasi, sehingga dapat mendorong auditor dalam meningkatkan kinerja menjadi lebih baik, dalam mewujudkan kualitas, kuantitass, ketepatan, dann kemandirian kinerjanya. Sedangkan penelitian yang dilakukan Faridah (2017) menunjukan hasil berbeda yaitu budaya organisasi tidak berpengaruh terhadap kinerja auditor.

Banyaknya persaingan di kalangan auditor dan berkembangnyaa profesi tersebut mewajibkan auditor untuk terus meningkatkan kinerjanya, sehingga mampuu menjadi auditor yang berkualitas dan mampu mengeluarkan produk berkualitas tinggi. Auditor dalam menjalankan tugasnya berpedoman dengan Standar audit. Realita pada saat ini menunjukkan banyaknya auditor yang melakukan penyimpangan pada kode etik dan standar audit (Irawati et al. 2005) dalamm Mindarti (2015). Penyimpangan pada standar dan prosedur audit dapat mempengaruhi kinerja auditor, selain itu dapat mengakibatkan kegagalann audit, serta berhubungan dengan auditors menganalisa kecurangan yang terjadi pada laporan keuangan.

Berdasarkan uraian diatas maka pokok permasalahan dalam penelitian ini sebagai berikut: 1) Apakah Kompetensi berpengaruh pada Kinerja Auditor di KAP Provinsi Bali?; 2) Apakah Locus Of Control berpengaruh pada Kinerja Auditor di KAP Provinsi Bali?; 3) Apakah Budaya Organisasi memoderasi pengaruh 
Kompetensi pada Kinerja Auditor di KAP Provinsi Bali?; 4) Apakah Budaya Organisasi memoderasi pengaruh Locus Of Control pada Kinerja Auditor di KAP Provinsi Bali?. Adapun tujuan yang ingin dicapai dalam penelitian ini sebagai berikut: 1) Untuk mengetahui pengaruh Kompetensi pada Kinerja Auditor di KAP Provinsi Bali; 2) Untuk mengetahui pengaruh Locus Of Control pada Kinerja Auditor di KAP Provinsi Bali; 3) Untuk mengetahui moderasi Budaya Organisasi dengan Kompetensi pada Kinerja Auditor di KAP Provinsi Bali; 4) Untuk mengetahui moderasi Budaya Organisasi dengan LocusoOffControl pada Kinerja Auditor KAP di ProvinsiiBali.

Teori Agensi (Agency Theory) merupakan teori yang mendeskripsikan konflik yang terjadi antara pihak manajemen perusahaan selaku agen dengan pemilik perusahaan sebagai principal. Melalui laporan pertanggung jawaban yang di buat agen, principal mendapat informasi yang diperlukan dan juga digunakan sebagai penilaian atas kinerja agen selamaa periode tertentu. Namunn yang terjadi adalah kecenderungan manajemen melakukan berbagai tindakan agar laporan pertanggung jawaban terlihat baik dan menguntungkan bagi principal, maka kinerja agen di anggap baik. Untuk meminimalisir hal itu, membutuhkan pemeriksaan oleh pihak lain yang independen, yaitu auditors. Sehingga, laporan keuangan yang di buat oleh manajemen dapat lebih reliabel (di percaya).

Teori keagenan menunjang auditors selaku pihak ketiga dalam menafsirkan masalah yang terjadi antara prinsipal dan agen (Mawar, 2010). Dengan hadirnya 
ISSN: 2302-8556

auditors, peluang kecurangan pada laporan keuangan yang di buat oleh manajemen tidak akan terjadi, selain itu dapat di gunakan sebagai sarana dalam mengevaluasi kinerja agen. Sehingga dapat menghasilkan informasi relevan yang dapat berguna untuk investor dan kreditor dalam pengambilan keputusan.

Kinerja bersumber dari kata prestasi kerja (job performance) yang artinya hasil kerja secara kualitas dan kuantitas yang di capai oleh karyawan dalam menjalankan tugasnya sesuai tanggung jawab yang dipercayakan kepadanya (Mangkunegara, 2005). Trisnaningsih (2007) mendefinisikan kinerja auditor adalah pelaksanaan tugas pemeriksaan yang telah di selesaikan auditor pada waktu tertentu.

Ely dan Siti (2010:2) menjelaskan kompetensi adalah auditor wajib memmiliki kemampuan, keahlian, serta pengalaman untuk mengetahui kriteria serta dalam memastikan jumlah bukti yang di butuhkan untuk dapat mendukung kesimpulan yang akan di ambil. Bedard (1986) dalaml Lastanti (2005) mendefinisikan kompetensi sebagai seseorang yang mempunyai pengetahuan dan ketrampilan prosedural luas yang di tunjukkan dalam pengalaman audit. Spector dalam Munir \& Sajid (2010) mendefinisikan Locus of control sebagai gambaran dari sebuah kecondongan seorang individu yang mempercayai bahwa dirinya dapat mengontrol peristiwa yang terjadi pada hidupnya (internal) atau kendali atas peristiwa yang terjadi bersumber dari hal lain, seperti nasib (eksternal). Locus of control merupakan salah satu faktor yang sangat menentukan perilaku individu. Locus of control dibedakan menjadi dua tipe, yaitu locus of control internal dan locus 
of control eksternal (Robbins, 2007:138). Locus of control internal yaitu individu percaya bahwa mereka yang memegang kendali atas apa pun yang terjadi pada diri mereka. Locus Of Control Eksternal yaitu individu memiliki keyakinan bahwa apa pun yang terjadi pada diri mereka di kendalikan oleh kekuatan luar seperti keberuntungan atau kesempatan.

Menurut Sutrisno (2007) budaya organisasi didefinisikan sebagai suatu perangkat sistem nilai(values), keyakinan(beliefs), asumsi(assumptions), atau norma yang sudah berlaku lama, di sepakati serta di ikuti oleh anggota organisasi yang digunakan sebagai dasar berperilaku dalam pemecahan masalah dalam organisasi. Budaya organisasi adalah kekuatan sosial yang tak terlihat, namun mampu mengendalikan semua orang dalam suatu organisasi untuk melakukan aktivitas kerja dan setiap orang dalam organisasi tersebut secara tidak sadar akan mempelajari budaya yang di anut dalam organisasi tersebut (Sutrisno, 2007).

Kerangka konseptual menunjukan pengaruh antar variabel dalam penelitian ini. Berdasarkan latar belakang dan kajian teoritis diatas maka dapat digambarkan kerangka konseptual dalam penelitian ini yang disajikan pada Gambar 1 seperti berikut. 
ISSN: 2302-8556

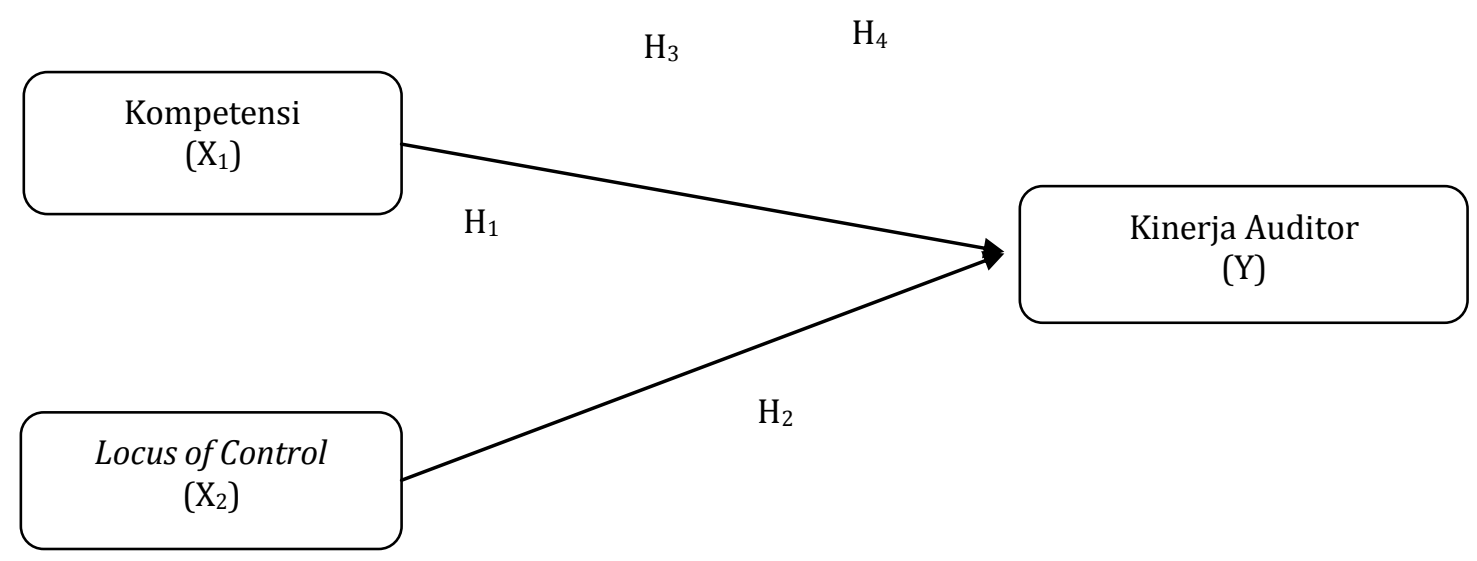

Gambar 1. Kerangka Konseptual

Kompetensi merupakan karakteristik mendasar seseorang yang menghasilkan kinerja unggul dan atau efektif dalam suatu pekerjaan. Semakin tinggi kompetensi yang di miliki seorang auditor dan sesuai dengan tuntutan pekerjaan maka dapat meningkatkan kinerja auditors karena auditors yang berkompeten biasanya mempunyai kemampuan serta kemauan cepat dalam mengatasi masalah kerja yang di hadapi. Dalam penelitian yang dilakukan oleh Endah (2011) menyebutkan bahwa kompetensi berpengaruh positif terhadap kinerja auditor, Begitu juga dalam penelitian yang dilakukan oleh Yusri (2013) menyebutkan bahwa Kompetensi secara parsial berpengaruh positif terhadap kinerja Auditor BPK RI Perwakilan Aceh. Berdasarkan uraian diatas dapat disimpulkan bahwa kompetensi berpengaruh terhadap kinerja auditor. Maka adapun hipotesis dalam penelitian ini: $\mathrm{H}_{1}$ : Kompetensi berpengaruh positif terhadap kinerja auditor.

Locus of control merupakan pemahaman individu tentang bagaimana sesuatu terjadi atau dominasi apa yang merangsang tindakannya. Dalam suasana penugasan 
audit yang komplek auditor akan di pengaruhi oleh karakter locus of controlnya. Auditor yang memiliki locus of control internal akan lebih siap dalam menghadapi masalah yang terjadi pada saat melaksanakan tugas audit di bandingkan dengan auditor dengan locus of control eksternal. auditor dengan locus of control internal memiliki kemungkinan yang kecil dalam pengambilan keputusan yang salah. Dalam hal ini, kemungkinan auditors tersebut mengambil keputusan yang lebih independent (Retnowati, 2009:20). Cara pandang auditor yang semakin baik pada suatu peristiwa maka akan dapat meningkatkan kinerjanya. Individu dengan locus of control mempunyai kepuasan yang sangat tinggi di bandingkan dengan individu tanpa locus of control. Dalam penelitian yang dilakukan oleh Julianingtyas (2012) yang menunjukkan bahwa locus of control berpengaruh positif terhadap kinerja auditor. Begitu juga dalam penelitian yang dilakukan oleh Faridah (2017) yang menunjukkan bahwa locus of control berpengaruh positif terhadap kinerja auditor. Selain itu didukung juga oleh penelitian Putra dan Ariyanto (2016), Sanjiwani dan Wisadha (2016). Berdasarkan uraian diatas dapat disimpulkan bahwa kompetensi berpengaruh terhadap kinerja auditors. Maka hipotesiss dalam penelitian ini:

$\mathrm{H}_{2}$ : Locus Of Control berpengaruh positif terhadap kinerja auditors.

Budaya Organisasi merupakan system yang dianut oleh organisasi agar berbeda dengan organisasi yang lain. Budaya organisasi dan lingkungan kerja yang kondusif berpengaruh pada hasil kerja yang di capai oleh auditor. Dengan adanya budaya organisasi dapat memberikan arah atau pedoman perilaku untuk auditor 
ISSN: 2302-8556

dalam suatu organisasi, di mana seorang auditor tidak boleh berperilaku semaunya melainkan perlu menyesuaikan dengan siapa dan di mana mereka berada. Dengan adanya Budaya Organisasi yang tinggi, auditor akan lebih berkompeten dalam menjalankan tugas-tugasnya yang pada akirnya dapat meningkatkan kinerjanya. Penelitian yang dilakukan oleh Yusri Kasim (2013) menyebutkan bahwa semakin baik kompetensi auditor maka dapat meningkatkan kinerja auditor, selanjutnya Nuraini (2016) menunjukkan bahwa Budaya Organisasi berpengaruh positif terhadap Kinerja Auditor. Berdasarkan uraian di atas dapat disimpulkan bahwa dengan adanya budaya organisasi dapat memperkuat pengaruh kompetensi terhadap kinerja auditor. Maka hipotesis dalam penelitian ini:

$\mathrm{H}_{3}$ : Budaya organisasi memperkuat pengaruh kompetensi terhadap kinerja auditor.

Budaya Organisasi adalah unsur terpenting dalam suatu perusahaan yang dasarnya mengarah ke perilaku yang di anggap tepat, mengikat dan memberi motivasi setiap orang dalam organisasi tersebut. Budaya Organisasi dapat memberikan dorongan pada prilaku yang di tanamkan organisasi untuk dapat menyelesaikan tugas dengan baik, serta menguntungkan bagi auditor tersebut. Akibatnya auditors akan mempunyai kepercayaan diri, kemandirian dan kagum terhadap diri sendiri. Sifat tersebut dapat meningkatkan harapan auditors agar kinerjanya juga semakin meningkat. Dalam penelitian yang dilakukan Syauffa (2016) menyebutkan bahwa semakin baik budaya organisasi yang diterapkan oleh auditor maka kinerja auditor akan semakin baik, selanjutnya penelitian yang dilakukan Listiya (2016) 
menunjukkan hasil bahwa Budaya Organisasi berpengaruh positif terhadap Kinerjaa Auditor. Berdasarkan uraian di atas dapat di simpulkan bahwa dengan adanya budaya organisasi dapat memperkuat pengaruh locus of control terhadap kinerja auditor. Maka hipotesis dalam penelitian ini:

$\mathrm{H}_{4}$ : Budaya organisasi memperkuat pengaruh locus of control terhadap kinerja auditor.

\section{METODE PENELITIAN}

Penelitian ini di lakukan pada Kantor Akuntan Publik yang berada di Provinsi Bali dan merupakan anggota Institusi Akuntan Publik Indonesia (IAPI). Pendekatan yang digunakan dalam penelitian ini adalah pendekatan kuantitatif yang berbentuk kausalitas. Penelitian ini menguji pengaruh variabel kompetensi dan locus of control pada kinerja auditor dengan budaya organisasi sebagai variabel pemoderasi.

Populasi dalam penelitian ini adalah seluruh auditor yang bekerja pada Kantor Akuntan Publik di Provinsi Bali, yang merupakan anggota IAPI tahun 2017 sebanyak 77 auditor. Sampel penelitian ini adalah individu yaitu auditor yang bekerja pada 9 Kantor Akuntan Publik di Provinsi Bali yaitu 77 auditor. Teknik penentuan sampel yang digunakan dalam penelitian ini adalah metode nonprobability sampling dengan teknik sampel jenuh atau sensus. Metode pengumpulan data dalam penelitian ini adalah metode observasi dengan teknik kuisioner yang diukur dengan menggunakan skala likert 1-5. Jenis data yang digunakan dalam penelitian ini adalah data kuantitatif yaitu hasil kuesioner yang berupa jawaban responden yang kemudian dikuantifikasi . 
ISSN: 2302-8556

E-Jurnal Akuntansi Universitas Udayana

Vol.23.3.Juni (2018): 1708-1735

Sumber data yang digunakan dalam penelitian ini adalah data primer yaitu data yang diperoleh diperoleh melalui metode survei berupa pernyataan responden dalam menjawab kuesioner

Definisi operasional variabel dependen pada penelitian ini adalah kinerja auditor (Y), Menurut Mulyadi (2002: 11) pengertian kinerja auditor merupakan akuntan publik yang melakukan tugas pemeriksaan (examination) secara obyektif pada laporan keuangan suatu perusahaan atau organisasii lain dengan tujuan menentukann apakah laporan keuangan tersebut menyajikan laporan secara wajar sesuai dengan prinsip akuntansi berlaku umum, dalam semua hal yang materiall, posisi keuangan dan hasil usaha perusahaan. Dalam penelitian ini kinerja auditors di ukur dengan menggunakan indikator yang di kembangkan oleh Listiya Nuraini (2016) dan sudah dimodifikasi, dengan indikator yaitu (1) ketepatan waktu, (2) kualitas kerja, (3) kuantitas kerja dan (4) kepuuasan kerja.

Definisi Operasional variabel independen dalam penelitian ini adalah:

1) Kompetensi $\left(\mathrm{X}_{1}\right)$, Kompetensi merupakan kemampuan dalam melaksanakan atau melakukan pekerjaan atau tugas yang di landasi keterampilan dan pengetahuan serta di dukung oleh sikap kerja yang di tuntut oleh pekerjaan (Wibowo, 2002). Kompetensi dalam penelitian ini di ukur dengan menggunakan indicator yang dikembangkan Budi Santoso (2011) dan sudah dimodifikasi. Indikator pengukuran dari kompetensi adalah (1) Pengetahuan Umum, (2) keahlian/ keterampilan khusus dan (3) pengalaman. 2) Locus Of Control $\left(\mathrm{X}_{2}\right)$, Locus of control adalah cara pandang 
seeseorang terhadap suatu peristiwa, apakah dia dapat atau tidak dapat mengendalikan (control) peristiwa tersebut. Locus Of Control dalam penelitian ini di ukur menggunakan indikator yang dikembangkan oleh Sanjiwani (2016) dan telah dimodifikasi. Indikator locus of control internal terdiri dari 3 aspek yaitu (1) Kemampuan; (2) Minat; dan (3) Usaha. Sedangkan Indikator locus of control eksternal di gunakan untuk mengungkap data tentang locus of control eksternal, Indikator locus of control exsternal terdiri dari 3 aspek yaitu (1) Nasib; (2) Sosial Ekonomi; dan (3) Pengaruh Orang Lain. 3) Budaya Organisasi ( $\left.\mathrm{X}_{3}\right)$, Budaya Organisasi (organization culture) merupakan sekumpulan nilai-nilai, keyakinan, dan pola perilaku yang membentuk identitas organisasi dan membantu membentuk perilaku pegawai (Rashid et al., 2003; Lund, 2003). Budaya Organisasi dalam penelitian ini di ukur dengan menggunakan indikator yang di kembangkan oleh Trisnaningsih (2007) dan telah dimodifikasi. Indikator pengukuran dalam Budaya organisasi adalah (1) Pengambilan keputusan dalam organisasi, (2) kepedulian terhadap masalah pegawai, (3) ikatan dengan masyarakat sekitar, (4) Perubahan ditentukan berdasarkan surat keputusan pimpinan dan (5) memepertahankan pegawai yang berprestasi.

Teknik analisis data yang digunakan untuk menguji hipotesis yang dirumuskan dalam penelitian ini adalah uji interaksi antar variabel yaitu Moderated Regression Analysis (MRA) yang diuji dengan tingkat signifikansi 0,05. Sebelum Moderated Regression Analysis (MRA) dilakukan, terlebih dahulu di lakukan uji 
instrument penelitian yang terdiri dari uji validitass dan uji reliabilitas. Apabila uji instrument sudah terpenuhi, selanjutnya di lakukan uji asummsi klasikk untuk menguji apakah model regresi tersebut baik atau tidak, yang terdiri dari uji normalitas, uji multikolinearitas dan uji heteroskedastisitass. Berdasarkan Moderated Regression Analysis (MRA) akan dilakukan uji parsial (Uji t), Uji Kelayakan Model ( Uji F), Koefisien determinasi $\left(\mathrm{R}^{2}\right)$

MRA dalam penelitian ini digunakan untuk menguji hubungan kompetensi dan locus of control pada kinerja auditor dimana budaya organisasi digunakan sebagai variabel pemoderasi. Model persamaan regresi dalam penelitian ini sebagai berikut:

$$
Y=\alpha+\beta_{1} X_{1}+\beta_{2} X_{2}+\beta_{3} X_{3}+\beta_{4} X_{1} X_{3}+\beta_{5} X_{2} X_{3}+e
$$

Keterangan:

$\mathrm{Y}=$ Kinerja auditor

$\alpha \quad=$ Konstanta

$\beta_{1}-\beta_{5} \quad=$ Koefesien regresi

$\mathrm{X}_{1} \quad=$ Kompetensi

$\mathrm{X}_{2} \quad=$ Locus of control

$\mathrm{X}_{3} \quad$ = Budaya organisasi

$\mathrm{X}_{1} \mathrm{X}_{3} \quad=$ Interaksi antara kompetensi dengan budaya organisasi

$\mathrm{X}_{2} \mathrm{X}_{3}=$ Interaksi antara locus of control dengan budaya organisasi

\section{HASIL DAN PEMBAHASAN}


Pengumpulan data pada penelitian ini dilakukan melalui penyebaran kuesioner pada 9 Kantor Akuntan Publik dengan responden sebanyak 67 auditor. Pengujian instrumen dilakukan terlebih dahulu untuk mengetahui kesungguhan responden dalam mengisi kuisioner. hasil uji validitas,disajikan pada tabel 1 berikut ini:

Tabel 1. Hasil Uji Validitas

\begin{tabular}{|c|c|c|c|}
\hline \multirow{2}{*}{ Variabel } & \multirow{2}{*}{ Indikator } & \multicolumn{2}{|l|}{ Uji Validitas } \\
\hline & & Koefisien Korelasi (r) & Keterangan \\
\hline \multirow{6}{*}{ Kompetensi } & $\mathrm{X}_{11}$ & 0,731 & Valid \\
\hline & $\mathrm{X}_{1.2}$ & 0,729 & Valid \\
\hline & $\mathrm{X}_{1.3}$ & 0,680 & Valid \\
\hline & $\mathrm{X}_{1.4}$ & 0,624 & Valid \\
\hline & $\mathrm{X}_{1.5}$ & 0,728 & Valid \\
\hline & $\mathrm{X}_{1.6}$ & 0,657 & Valid \\
\hline \multirow[t]{6}{*}{ Locus of control } & $\mathrm{X}_{2.1}$ & 0,605 & Valid \\
\hline & $\mathrm{X}_{22}$ & 0,603 & Valid \\
\hline & $\mathrm{X}_{23}$ & 0,583 & Valid \\
\hline & $\mathrm{X}_{2.4}$ & 0,604 & Valid \\
\hline & $\mathrm{X}_{2.5}$ & 0,629 & Valid \\
\hline & $\mathrm{X}_{2.6}$ & 0,701 & Valid \\
\hline \multirow[t]{5}{*}{ Budaya organisasi } & $\mathrm{X}_{3.1}$ & 0,664 & Valid \\
\hline & $X_{3.2}$ & 0,702 & Valid \\
\hline & $\mathrm{X}_{3.3}$ & 0,581 & Valid \\
\hline & $\mathrm{X}_{3.4}$ & 0,682 & Valid \\
\hline & $\mathrm{X}_{3.5}$ & 0,628 & Valid \\
\hline \multirow[t]{8}{*}{ Kinerja auditor } & $\mathrm{Y}_{1}$ & 0,774 & Valid \\
\hline & $\mathrm{Y}_{2}$ & 0,668 & Valid \\
\hline & $\mathrm{Y}_{3}$ & 0,757 & Valid \\
\hline & $\mathrm{Y}_{4}$ & 0,634 & Valid \\
\hline & $\mathrm{Y}_{5}$ & 0,737 & Valid \\
\hline & $\mathrm{Y}_{6}$ & 0,674 & Valid \\
\hline & $\mathrm{Y}_{7}$ & 0,792 & Valid \\
\hline & $\mathrm{Y}_{8}$ & 0,841 & Valid \\
\hline
\end{tabular}

Sumber : Data diolah, 2017

Berdasarkan tabel 1 dapat dilihat bahwa nilai kolerasi lebih besar dari 0,3 sehingga menunjukkan bahwa instrumen penelitian telah memenuhi syarat validitas. 
ISSN: 2302-8556

E-Jurnal Akuntansi Universitas Udayana

Vol.23.3.Juni (2018): 1708-1735

Uji Reliabilitas dalam penelitian ini ditunjukan pada tabel 2. Berdasarkan

Tabel 2 menunjukkan nilai masing-masing cronbach's alpha lebih besar dari 0,60 sehingga seluruh instrumen yang digunakan dalam penelitian ini dikatakan reliabel dimana keseluruhan instrument layak digunakan untuk mengumpulkan data.

Tabel 2.

Hasil Uji Reliabilitas

\begin{tabular}{lll}
\hline \multirow{2}{*}{ Variabel } & Uji Reliabilitas & \\
\cline { 2 - 3 } & AlphakCronbach'so & Keterangann \\
\hline Kompetensil & 0,779 & Reliabel \\
Locus of control & 0,672 & Reliabel \\
Budaya organisasi & 0,655 & Reliabel \\
Kinerja auditors & 0,876 & Reliabel \\
\hline
\end{tabular}

Sumber : Data diolah, 2017

Statistik deskriptif digunakan untuk memberikan gambaran mengenai data yang telah terkumpul. Berikut tabel 3 adalah hasil statistik deskriptif:

Tabel 3. Hasil Uji Statistik Deskriptif

\begin{tabular}{llllll}
\hline & N & Minimum & Maximum & Mean & Std. Deviation \\
\hline Kompetensi & 67 & 17.00 & 27.00 & 22.99 & 2.11 \\
Locus_of_Control & 67 & 16.00 & 30.00 & 22.28 & 2.32 \\
Budaya_Organisasi & 67 & 14.00 & 24.00 & 17.93 & 2.27 \\
Kinerja_Auditor & 67 & 23.00 & 40.00 & 31.15 & 3.57 \\
\hline
\end{tabular}

Sumber : Data diolah, 2017

Berdasarkan hasil uji statistik deskriptif pada Tabel 3 nilai rata-rata kompetensi adalah sebesar 22,99 hampir mendekati nilai terbesarnya daripada nilai minimumnya. Rata-rata jawaban responden berpendapat dengan skor mendekati skor maksimal, berarti bahwa rata-rata responden berpendapat, indikator dari variabel kompetensi cenderung dapat meningkatkan kinerja auditor. Nilai rata-rata locus of 
control sebesar 22,28, menunjukkan secara rata-rata jawaban responden cenderung tidak mengadah pada nilai maksimum maupun minimum namun lebih pada nilai tengah yang artinya responden cenderung menilai locus of control masih dalam taraf yang wajar namun belum dilakukan secara maksimal.

Nilai rata-rata budaya organisasi yaitu 17,93 menunjukkan rata-rata jawaban responden cenderung kepada nilai tertinggi. Variabel budaya organisasi mempunyai nilai rata-rata tinggi yang menggambarkan bahwa pendapat responden menyatakan budaya organisasi dapat meningkatkan kinerja auditor. Nilai rata-rata kinerja auditor diperoleh nilai rata-rata 31,15 dan hampir mendekati nilai skor maksimum, mengindikasikan bahwa rata-rata jawaban responden pada variabel kinerja auditor mengarah pada kinerja auditor yang tinggi. Penelitian ini menggunakan 67 data yang tellah dilakukan uji asumsi klasik dan memenuhi criteria pengujian asumsi klasik. Berikut merupaka hasil uji normalitas menunjukkan bahwa nilai Test Statistic sebesar -0,099 dengan nilai Asymp Sig (2-tailed) sebesar 0,171 > 0,05 menunjukkan bahwa data yang digunakan dalam persamaan regeresi merupakan data yang berdistribusi normal.

Berdasarkan hasil uji heteroskedastisitas menunjukkan bahwa tingkat signifikansi tiap variabel bebas > 0,05 Jadi dapat disimpulkan bahwa pada model regresi tidak ditemukan gejala heteroskedastisitas. Berdasarkan hasil uji multikolinearitas pada tabel 6 menunjukan bahwa nilai tolerance masing-masing 
ISSN: 2302-8556

E-Jurnal Akuntansi Universitas Udayana

Vol.23.3.Juni (2018): 1708-1735

variabel bebas $>0,1$ dan nilai $\mathrm{VIF}<10$. Maka dapat disimpulkan bahwa tidak terdapat gejala multikolinearitas.

Teknik analisis data adalah teknik pengolahan data yang terkumpul dankemudian diinterpretasikan hasil dari analisis tersebut yang akan digunakan untuk menjawab permasalahan yang dirimuskan.

\section{Tabel 4.}

Hasil Analisis Moderasi

\begin{tabular}{llllll}
\hline \multirow{2}{*}{ Variabel } & \multicolumn{2}{l}{$\begin{array}{l}\text { Unstandardized } \\
\text { Coefficients }\end{array}$} & $\begin{array}{l}\text { Standar } \\
\text { Coefficients } \\
\text { Beta }\end{array}$ & T & Sig. \\
\cline { 2 - 5 } & B & Std. Error & & $-0,914$ & 0,364 \\
\hline (Constant) & $-0,092$ & 0,100 & & 3,059 & 0,003 \\
Kompetensi & 0,321 & 0,105 & 0,321 & 2,382 & 0,020 \\
Locus of control & 0,257 & 0,108 & 0,257 & 3,059 & 0,003 \\
Moderasi 1 & 0,320 & 0,105 & 0,351 & 2,059 & 0,044 \\
Moderasi 2 & 0,244 & 0,118 & 0,240 & & \\
F & & 8,626 & & & \\
Sig F & & 0,000 & & & \\
R Square & 0,414 & & & \\
Adjusted RSquare & 0,366 & &
\end{tabular}

Berdasarkan Tabel 4 di ketahui bahwa besarnya nilai Adjusted Rsquare sebesar 0,366 memiliki arti 36,6 persen variabel kinerja auditor di jelaskan oleh variabel kompetensi dan locus of control yang di moderasi oleh budaya organisasi. Sedangkan sisanya sebesar 63,4 persen di jelaskan oleh variabel lain yang tidak di masukkan dalam model penelitian.

Uji $\quad F$ menghasilkan $F_{\text {hitung }}$ sebesar 8,626 dengan tingkat signifikansi sebesar 0,000 yang lebih kecil dari nilai $\alpha=0,05$ ( $\alpha=5$ persen), yang berarti bahwa model 
yang di gunakan dalam penelitian ini telah layak (fit). Dengan demikian model penelitian yang di gunakan layak dan pembuktian hipotesis dapat di lanjutkan.

Pada tabel 7 dapat dilihat nilai koefisien regresi dari variabel kompetensi, locus of control, budaya organisasi dan kinerja auditor (konstansta), sehingga secara sistematis diperoleh persamaan sebagai berikut :

$Y=-0,092+0,321 X_{1}+0,257 X_{2^{-}} 0,065 X_{3}+0,320 X_{1} X_{3}+0,244 X_{2} X_{3}$ e

Berdasarkan model persamaan regresi tersebut dapat dijelaskan informasi Nilai konstanta dengan adanya moderasi budaya organisasi adalah -0,092, artinya apabila variabel kompetensi, locus of control dan budaya organisasi dan interaksi antara variabel independen dengan moderasi (moderasi 1 dan moderasi 2) ada atau sama dengan 0 (nol), maka kinerja auditor cenderung akan mengalami penurunan. Nilai koefisien regresi variabel kompetensi 0,321 artinya peningkatan pada variabel kompetensi akan diikuti oleh peningkatan pada kinerja auditor dengan asumsi variabel lain konstan. Nilai koefisien regresi variabel locus of control 0,257 artinya peningkatan pada variabel locus of control akan diikuti oleh peningkatan pada kinerja auditor dengan asumsi variabel lain konstan. Nilai koefisien regresi moderasi $\left(\mathrm{X}_{1} . \mathrm{X}_{3}\right)$ adalah 0,320 dengan tingkat signifikan sebesar 0,003, artinya apabila teraksi variabel kompetensi dan budaya organisasi meningkat sebesar 1 satuan, maka variabel kinerja auditor cenderung akan mengalami peningkatan dengan asumsi bahwa variabel bebasnya lain adalah konstan atau tidak mengalami perubahan. Nilai koefisien regresi moderasi $\left(\mathrm{X}_{1} . \mathrm{X}_{3}\right)$ adalah 0,244 dengan tingkat signifikansi sebesar 0,044, artinya 
ISSN: 2302-8556

apabila interaksi variabel locus of control dan budaya organisasi meningkat sebesar 1 satuan, maka variabel kinerja auditor cenderung akan mengalami peningkatan dengan asumsi bahwa variabel bebasnya lainnya adalah konstan atau tidak mengalami perubahan.

Uji Parsial (Uji t) di lakukan agar mengetahui apakah ada pengaruh yang signifikan secara individu antar variabel independent dalam menerangkan variabel dependent. Pengaruh Kompetensi pada Kinerja auditor, oleh kerena nilai $t_{\text {hitung }}$ sebesar 3,059 $>1,669 t_{\text {tabel }}$, dengan tingkat signifikansi 0,003 $<0,05$, maka Ho ditolak. Hal ini berarti terdapat pengaruh yang signifikan secara parisal kompetensi terhadap_kinerja auditor KAP di Provinsi Bali. Pengaruh Locus of Control pada Kinerja auditor, oleh karena nilai $t_{\text {hitung }}$ sebesar 2,382 > 1,669 $t_{\text {tabel }}$ dengan tingkat signifikansi $0,020<0,05$, maka Ho ditolak. Hal ini berarti terdapat pengaruh yang signifikan secara parisal Locus of Control terhadap kinerja auditor KAP di Provinsi Bali. Pengaruh Moderasi Kompetensi terhadap Kinerja auditor melalui Budaya Organisasi, oleh karena nilai $t_{\text {hitung }}$ sebesar 3,059>1,669 $t_{\text {tabel }}$ dengan nilai signifikansi $0,003<0,05$, maka Ho ditolak. hal ini menunjukkan bahwa budaya organisasi mampu memoderasi pengaruh kompetensi terhadap kinerja auditor KAP di Provinsi Bali. Pengaruh Moderasi Locus of Control terhadap Kinerja auditor melalui Budaya Organisasi, oleh karena $t_{\text {hitung }}$ sebesar 2,059 > 1,669 $t_{\text {tabel }}$ dengan 
nilai signifikansi $0,044<0,05$, hal ini menunjukkan bahwa budaya organisasi mampu memoderasi pengaruh locus of control terhadap kinerja auditor KAP di Provinsi Bali.

Berdasarkan hasil analisis regresi pada Tabel 4 diatas, diketahui bahwa nilai signifikan variabel kompetensi sebesar 0,003 dan memiliki nilai koefisien sebesar 0,321. Sehingga hipotesis pertama $\left(\mathrm{H}_{1}\right)$ diterima. Hal ini menunjukan bahwa kompetensi berpengaruh positif terhadap kinerja auditor. Hal ini terjadi karena kompetensi yang tinggi di miliki auditor dan sesuai dengan tuntutan pekerjaan maka kinerja auditors akan semakin meningkat karenaa auditor yang berkompeten biasanya memiliki kemampuan serta kemauan cepat dalam mengatasi masalah kerja yang di hadapi, melakukan pekerjaan dengan tenang dan penuh rasa percaya diri, memandang pekerjaan sebagai suatu kewajiban yang harus di lakukan ikhlas, dan meningkatkan kualitas diri melalui proses pembelajaran.

Berdasarkan hasil analisis regresi berganda pada Tabel 4 di atas, diketahui bahwa nilai signifikan variabel locus of control sebesar 0,020 dan memiliki nilai koefisien sebesar 0,321. Sehingga hipotesis kedua $\left(\mathrm{H}_{2}\right)$ di terima. Hal tersebut menunjukan bahwa locus of control berpengaruh positif dan signifikan terhadap kinerja auditors. Hal ini terjadi karena semakin baik cara pandang auditors terhadap peristiwa maka akan semakin tinggi kinerjanya. Hal ini terjadi karena locus of control berperan motivasi serta mengendailkan stress. Individu yang mempunyai locus of control memiliki kepuasan yang lebih tinggi dibandingkan dengan individu yang tidak mempunyai locus of control. 
ISSN: 2302-8556

Berdasarkan hasil analisis moderasi pada Tabel 4 di atas, diketahui bahwa nilai signifikansi variabel budaya organisasi mempengaruhi kompetensi sebesar 0,003 dan memiliki nilai koefisien sebesar 0,320. Dengan demikian budaya organisasi terbukti sebagai variabel moderasi. Hal ini menunjukan bahwa Budaya organisasi memperkuat pengaruh kompetensi terhadap kinerja auditor. Secara umum hal ini menggambarkan bahwa kompetensi mampu meningkatkan kinerja auditor apabila didukung oleh budaya organisasi yang baik. Dengan adanya Budaya Organisasi yang tinggi, auditor akan lebih berkompeten dalam menjalankan tugas-tugasnya yang pada akirnya dapat meningkatkan kinerjanya.

Berdasarkan hasil analisis moderasi pada Tabel 4 di atas, diketahui bahwa nilai signifikan variabel budaya organisasi mempengaruhi locus of control sebesar 0,044 dan memiliki nilai koefisien sebesar 0,244. Dengan demikian, budaya organisasi terbukti sebagai variabel moderasi. Hal ini menunjukan bahwa Budaya organisasi memperkuat pengaruh locus of control terhadap kinerja auditor. Secara umum hasil ini menggambarkan bahwa locus of control mampu meningkatkan kinerja auditor apabila didukung dengan budaya organisasi yang baik. Budaya Organisasi dapat memberi sugesti pada prilaku yang di tanamkan organisasi supaya dapat menyelesaikan tugas dengan baik yang nantinya dapat memberikan keuntungan untuk auditor itu sendiri.

Implikasi Teoritis pada penelitian ini dapat memberikan tambahan informasi mengenai budaya organisasi memoderasi pengaruh kompetensi dan locus of control 
pada kinerja auditor. Terdapat bukti empiris dalam penelitian ini yaitu budaya organisasi memperkuat pengaruh kompetensi dan locus of control pada kinerja auditor. Hal ini menunjukan bahwa kompetensi dan locus of control yang tinggi dan didukung dengan budaya organisasi yang baik maka dapat meningkatkan kinerja auditor. Hal tersebut didukung dengan adanya teori keagenan bahwa dengan teori keagenan dapat membantu auditor sebagai pihak ketiga dalam memahami permasalahan yang terjadi antara prinsipal dan agennya. Sedangkan implikasi praktis pada penelitian ini dapat digunakan sebagai masukan bagi auditor untuk menambah pengalaman, melakukan pelatihan dan mengendalikan suatu peristiwa yang terjadi, baik dari individu maupun kekuatan luar seperti keberuntungan dan kesempatan, agar dapat meningkatkan kompetensi dan locus of control yang didukung dengan penerapan budaya organisasi yang nantinya dapat meningkatkan kinerja auditor.

\section{SIMPULAN}

Berdasarkan hasil analisis serta pembahasan sebelumnya maka dapat di simpulkan: 1) Kompetensi berpengaruh positif dan signifikan terhadap kinerja auditor. Hal ini ber arti semakin tinggi kompetensi yang di miliki oleh auditors dan sesuai tuntutan pekerjaan maka dapat meningkatkan kinerja auditors. 2) Locus of control berpengaruh positif dan signifikan terhadap kinerja auditor. Hal tersebut berarti semakin baik cara pandang auditors pada suatu peristiwa maka akan semakin tinggi pula kinerjanya. 3) Budaya organisasi memperkuat pengaruh kompetensi terhadap kinerja auditor, yang berarti kompetensi secara signifikan mampu meningkatkan 
ISSN: 2302-8556

kinerja auditor apabila di dukung oleh budaya organisasi yang baik. 4) Budaya organisasi memperkuat pengaruh locus of control terhadap kinerja auditor, yang berarti locus of control yang di dukung oleh budaya organisasi yang baik secara signifikan mampu meningkatkan kinerja auditor.

Berdasarkan simpulan diatas, maka saran penelitian yang dapat disampaikan antara lain: 1) Bagi Penelitian Selanjutnya, karena hasil nilai adjusted R Square sebesar 0,366 yang berarti 33,6 persen mengindikasikan bahwa terdapat 63,4 persen variabel kinerja auditor dijelaskan oleh variabel diluar model. Maka hal ini membuka peluang bagi peneliti selanjutnya untuk menambahkan variabel lain yang diduga berpengaruh terhadap kinerja auditor. 2) Bagi Kantor Akuntan Publik, Kepada auditors yang bekerja di KAP di sarankan agar terus meningkatkan kompetensi kerja dengan mengikuti pelatihan dan seminar dengan taraf nasional maupun internasional, selain itu diharapkan memiliki locus of control yang semakin baik yang di ikuti oleh budaya organisasi yang tinggi sehingga mampu menunjang kinerja auditor dalam melakukan audit laporan keuangan.

\section{REFERENSI}

Arens, Alvin A., Randal J. Elder, \& Mark S. Beasley. 2013. Auditing dan Jasa Assurance : Pendekatan Integrasi. (Alih Bahasa: Herman Wibowo). Jilid 1. Edisi Kedua belas. Jakarta: Penerbit Erlangga.

Ayudiati, Soraya Eka. 2010.Analisis Pengaruh Locus of Control Terhadap Kinerja dengan Etika Kerja Islam sebagai variabel moderating (studi pada karyawan tetap Bank Jateng Semarang). Skripsi. Undip. 
Endah Wulandari. 2011. "Pengaruh Kompetensi, Independensi, dan komitmen organisasi terhadap kinerja auditor pada BPKP perwakilan DIY". Jurnal Ekonomi dan Bisnis, 1 (1), pp. 31-41

Ely Suhayati., \& Siti Kurnia Rahayu. 2010. AUDITING, Konsep Dasar dan Pedoman Pemriksaan Akuntan Publik. Yogyakarta : Graha Ilmu.

Faridah Husnun Pratiwi. 2017. Pengaruh Locus Of Control, Gaya Kepemimpinan, Budaya Organisasi, Serta Pengaruh Pemahaman Good Governance Terhadap Kinerja Auditor. Jurnal Ekonomi dan Bisnis, 1(1), pp. 3-9

Fitriany. (2010). Analisis Komprehensif Pengaruh Independensi dan Kompetensi Auditor terhadap Kualitas Audit. Disertasi Pascasarjana Ilmu Akuntansi Universitas Indonesia.

Ghozali, Imam. 2013. Aplikasi Analisis Multivariate Dengan program SPSS. Edisi Tujuh. Badan Penerbit Universitas Diponegoro, Semarang.

Julianingtyas, Bunga Nur. 2012. Pengaruh Locus Of Control, Gaya Kepemimpinan dan Komitmen Organisasi Terhadap Kinerja Auditor. Accounting Analysis Journal, 1 (1), pp. 8-12

Lastanti, Hexana Sri. 2005. Tinjauan Tesrhadap Kompetensi dan Independensi Akuntan Publik : Refleksi Atas Skandal Keuangan. Jurnal Akuntansi, Auditing dan Informasi, 5 (1), pp: 85-97.

Listiya Nuraini. 2016. Pengaruh Independensi, Gaya Kepemimpinan dan Budaya Organisasi Terhadap Kinerja Auditor. Skripsi Sarjana Juruusan Akuntansi pada Universitas Negeri Yogyakarta.

Mangkunegara. Anwar Prabu. 2005. Sumber Daya Manusia perusahaan. Remaja Rosda karya: Bandung.

Mindarti, Ceacilia Sri. 2015. Pengaruh Karakteristik Individu Terhadap Kinerja Auditor. Jurnal Ekonomi dan Bisnis, 8 (3), pp.59-74

Mulyadi. 2002. Pemeriksaan Akuntan. Yogyakarta: Badan Penerbit STIE

Munir, S \& Sajid, M. 2010. Examining locus of control (LOC) as a Determinant of Organizational Commitment among University Professors in Pakistan. Journal of Bisiness Studies Quarterly; 1 (3), pp:78-93. 
ISSN: 2302-8556

E-Jurnal Akuntansi Universitas Udayana

Vol.23.3.Juni (2018): 1708-1735

Putra Kadek Arya Adi dan Dodik Ariyanto. 2016. Gaya Kepemimpinan, Pemahaman Good Governance, Locus Of Control, Struktur Audit dan Komitmen Organisasi. ISSN: 2303-1018 E-Jurnal Akuntansi Universitas Udayana, 14(1), pp.340-370

Retnowati, Reni. 2009. "Pengaruh Keahlian Audit, Kompleksitas Tugas dan Locus of Control Terhadap Audit Judgment", Skripsi Fakultas Ekonomi dan Ilmu Sosial, Universitas Islam Negeri Syarif Hidayatullah, Jakarta.

Robbins, S.P. 2009. Organizational Behavior: Global and Southern African Perspective. Capetown: Pearson Education South Africa.

Safitri, Devi. 2014. Pengaruh Independensi Auditor Dan Gaya Kepemimpinan Terhadap Kinerja Auditor Dengan Komitmen Organisasi Sebagai Variabel Intervening (Studi Empiris : Kantor Akuntan Publik Pekanbaru, Batam, Dan Medan). Jurnal Ilmiah Ekonomi dan Bisnis, 11 (2), pp.339 - 351.

Sanjiwani, Desak Made Putri dan I Gede Suparta Wisadha. 2016. Pengaruh Locus Of Control, Gaya Kepemimpinan dan Komitmen Organisasi Pada Kinerja Auditor Kantor Akuntan Publik. ISSN: 2302-8556 E-Jurnal Akuntansi Universitas Udayana, 14(2), pp.920-947.

Sitio, Ristina dan Indah Anisykurlillah. 2014. Pengaruh Pemahamam Good Governence, Gaya Kepemimpinan, Budaya Organisasi dan Struktur Audit Terhadap Kinerja Auditor (Studi Empiris pada Kantor Akuntan Publik di Kota Semarang). ISSN 2252-6765. Jurnal Ilmiah Ekonomi dan Bisnis, 3 (3), pp.301-309

Sugiyono. 2013. Metodelogi Penelitian Bisnis Pendekatan Kuantitatif. Bandung:Alfabeta.

Setiawan, Ivan Aries dan Ghozali, "Akuntansi Perilaku", Edis, Badan Penerbit Universitas Diponegoro, Semarang, 2006.

Trisnaningsih, S. 2007. Independensi Auditor dan Komitmen Organisasi Sebagai Mediasi Pengaruh Pemahaman Good corporate governance, Gaya Kepemimpinan dan Budaya Organisasi Terhadap Kinerja Auditor. Simposium Nasional Akuntansi X. Makassar. Jurnal Ekonomi dan Bisnis, 10 (2), pp.1-56

Wibowo, Hian Ayu Oceani. 2002. Pengaruh Independensi Auditor, Komitmen Organisasi, Gaya Kepemimpinan, dan Pemahaman Good Governance terhadap Kinerja Auditor (Studi Empiris pada Kantor Akuntan Publik di 
I Dewa Ayu Yulia Rusmita dan I Dewa Nyoman Badera. Budaya ...

Daerah Istimewa Yogyakarta). Tesis. Fakultas Ekonomi Universitas Islam Indonesia.

Yusri Kalsim. 2013. “Pengaruh Akuntabilitas, Kompetensi, Dan Kompleksitas Tugas Terhadap Kinerja Auditor". Jurnal Akuntansi Pascasarjana Universitas Syiah Kuala ISSN 2302-0164, 2 (2), pp.103-116 